\title{
The Feasibility of Conventional and Environmentally Friendly Shallot Farming at Selopamioro Village Bantul Regency
}

\author{
Diah Rina Kamardiani ${ }^{1, *}$ and Retno Wulandari ${ }^{2}$ \\ ${ }^{1}$ Department of Agribusiness, Universitas Muhammadiyah Yogyakarta, Indonesia \\ ${ }^{2}$ Student of Department of Agribusiness, Universitas Muhammadiyah Yogyakarta, Indonesia
}

\begin{abstract}
Yogyakarta Special Region did not include the production center of shallots in Indonesia, but farmers in Selopamioro Village, Imogiri District, Bantul Regency have used biological pesticide input. This study determines the costs, benefits, and feasibility of environmentally friendly and conventional shallot farming in Selopamioro Village, Bantul Regency. The research location is in Nawungan Hamlet as a shallot center that uses biological pesticide input. Respondents, each as many as 35 farmers taken by census on environmentally friendly shallot farmers, and simple random from conventional shallot farmers. Descriptive analysis was used to determine the cost, benefits, and feasibility of farming. The results showed that the production per hectare was $13.8 \%$ lower in environmentally friendly shallots, namely 7,876 tons/ha. The environmentally friendly shallot farming costs are $30.54 \%$ lower than the conventional shallot farming costs, but the profits obtained are $12.39 \%$ higher. Both farms are feasible, but land, capital, labor, and $\mathrm{R} / \mathrm{C}$ values are higher in environmentally friendly shallot farming.
\end{abstract}

\section{Introduction}

Shallots (Allium ascalonicum L.) is a tuber vegetable for flavoring dishes and is needed every day and all the time by end consumers, restaurants, hotels, and the processed industry. Shallots are a strategic commodity that drives national development from horticultural crops. Referring to Table 1 (the most production is in 10 provinces out of 34 shallot-producing provinces). For five years, namely 2015-2019, Shallot production centers in Indonesia are still in four provinces: Central Java, East Java, West Java, and West Nusa Tenggara [1,2]. The production of shallots in these production centers still applies conventional farming systems with the intensive use of synthetic fertilizers and pesticides. One of the obstacles in cultivation is the high use of chemical fertilizers and pesticides. Data from the Indonesian Organic Agriculture System (SPOI) in 2017 shows that there is no organic shallot production in the production center areas [3].

\footnotetext{
*Corresponding author: kamardiani@umy.ac.id
} 
Table 1. Shallot Production by Province, the Year 2015-2019 (ton)

\begin{tabular}{|c|l|r|r|r|r|r|}
\hline \multirow{2}{*}{ No. } & \multirow{2}{*}{ Province } & \multicolumn{5}{|c|}{ Year } \\
\cline { 3 - 7 } & & $\mathbf{2 0 1 5}$ & $\mathbf{2 0 1 6}$ & $\mathbf{2 0 1 7}$ & $\mathbf{2 0 1 8}$ & $\mathbf{2 0 1 9}$ \\
\hline 1 & Central Java & 546,685 & 471,169 & 476,337 & 445,586 & 481,890 \\
\hline 2 & East Java & 277,121 & 304,521 & 306,316 & 367,032 & 407,877 \\
\hline 3 & West Java & 129,148 & 141,504 & 166,865 & 167,770 & 173,463 \\
\hline 4 & West Nusa Tenggara & 211,804 & 160,201 & 195,458 & 212,885 & 188,255 \\
\hline 5 & West Sumatra & 61,568 & 66,543 & 95,534 & 113,864 & 122,399 \\
\hline 6 & South Sulawesi & 96,256 & 69,889 & 129,181 & 92,392 & 101,762 \\
\hline 7 & Bali & 18,024 & 10,147 & 20,287 & 24,267 & 19,687 \\
\hline 8 & North Sumatra & 13,368 & 9,971 & 16,103 & 16,337 & 18,072 \\
\hline 9 & DI Yogyakarta & 12,241 & 8,799 & 13,980 & 14,950 & 16,999 \\
\hline 10 & Jambi & 4,940 & 3,936 & 8,941 & 10,058 & 9,686 \\
\hline
\end{tabular}

Source: [1]

Conventional farming systems are agricultural systems that still use synthetic fertilizers and pesticides. Organic farming systems are holistic production management systems to improve and develop agro-ecosystem health, including biodiversity, biological cycles, and soil biological activities [4]. Meanwhile, an environmentally friendly agricultural system is a sustainable agricultural system that aims to increase and maintain high productivity by paying attention to the supply of nutrients. This system uses organic materials, minimizes inorganic fertilizers, improves soil biota, controls plant pest organisms (OPT) based on ecological conditions, and diversifies crops [5]. One of the obstacles in cultivating shallots in production centers is the high use of chemical fertilizers and pesticides. Irrational use of chemicals harms food safety and environmental sustainability. This condition can be overcome by using environmentally friendly Plant Destruction Organisms (OPT) control materials such as biological control agents, vegetable pesticides [6]

The Special Region of Yogyakarta is not included in the four largest shallot production centers in Indonesia. However, Bantul Regency, especially Selopamioro Village, Imogiri District, has implemented an environmentally friendly agricultural system since 2010 . In addition, production growth is higher than the production centers of Central Java, West Java, and East Java, which reached 39.12 percent in 2016 [7]. Selopamioro Village farmers do not use synthetic pesticides that contain toxic materials harmful to human health and the environment. In June 2018, some shallot farmers in Nawungan Hamlet, Selopamioro Village, had their first harvest of organic shallot farming [8]. Farmers in Selopamioro Village, especially Nawungan Hamlet, are different from other farmers in Bantul.

The shallot cultivation system is environmentally friendly in Selopamioro Village because the farmers have not fully implemented the organic farming system. Farmers are limited to using organic fertilizers and vegetable pesticides, so the land is not free from artificial pesticide residues. This condition is caused farmers still apply conventional farming systems to cultivate rice plants planted before shallots. The environmentally friendly or conventional farming system carried out by farmers in Selopamioro Village affects production inputs, costs, productions, and profits. In addition, an environmentally friendly agricultural system will reduce the content of chemical pesticide residues that are harmful to consumer health. Supported by the statement [9] that the contribution of chemical fertilizers will cause environmental degradation, and chemical residues also accumulate in plant tissues and persist until consumed by humans.

From the explanation above, it is important to research the differences in costs, benefits, and feasibility of environmentally friendly shallot farming with conventional shallot 
farming in Selopamioro Village, Imogiri District Bantul Regency. The results of this study will be beneficial as a consideration in developing environmentally friendly shallots.

\section{Research Method}

This research was conducted in Selopamioro Village, Imogiri District, Bantul Regency, where farmers have used organic fertilizers and pesticides. The system, namely an environmentally friendly shallot cultivation system. The research location was determined purposively, namely Dusun Nawungan 1 and Hamlet Nawungan 2. Dusun Nawungan 1 became an environmentally friendly shallot area, and Hamlet Nawungan 2, with the largest number of farmers applying conventional shallot cultivation in Selopamioro Village. Determination of each respondent as many as 35 farmers. The sample of environmentally friendly shallot farmers used the census technique, and sample random sampling was used for the sample of conventional shallot farmers.

Descriptive analysis was used to determine the costs, benefits, and feasibility of shallots farming of the two cultivation systems. Data analysis uses the same land area, namely per hectare. The calculation of costs, benefits, and feasibility of farming uses the following formula:

\subsection{Total Cost}

$$
T C=T E C+T I C
$$

Description

TC : Total Cost (IDR)

TEC : Total Explisit Cost (IDR)

TIC : Total Implicit Cost (IDR)

\subsection{Profit}

$$
\Pi=T R-T C \quad \text { Which }: T R=P . Y
$$

Description:

$\begin{array}{ll}\mathrm{TR} & : \text { Total revenue (IDR) } \\ \mathrm{P} & : \text { Price (IDR } / \mathrm{kg}) \\ \mathrm{Y} & : \text { Production }(\mathrm{kg})\end{array}$

\subsection{Feasibility Farming}

The feasibility of farming is measured using:

\subsection{1 $R / C$ ratio}

$$
R / C \text { ratio }=\frac{T R}{T C}
$$

Description:

$\mathrm{R} / \mathrm{C} \quad$ : Revenue Cost Ratio

TR : Total Revenue

TC : Total Cost 
the feasibility criteria of a farm, namely [10]:

$\mathrm{R} / \mathrm{C}>1$, then shallots farming is feasible to cultivate,

$\mathrm{R} / \mathrm{C}<1$, then shallot farming is not feasible to cultivate, and

$\mathrm{R} / \mathrm{C}=1$, then red shallots farming is neither profitable nor loss.

\subsubsection{Land productivity}

$$
\text { Land productivity }=\frac{N R-F L-O w n \text { capital interest })}{\text { land area }\left(m^{2}\right)}
$$

Description:

NR : Net Revenue

FL : Family Labor

If the land productivity is of the prevailing land rent, then farming is feasible to cultivate. If the productivity is less than the prevailing land rent, then farming is not feasible to cultivate.

\subsubsection{Labor Productivity}

Labor productivity $=(N R-$ own land rent - own capital interest $) /$ amount of $F L$

If the value of labor productivity is higher than the wage of labor in the local area, then shallots farming is feasible. If the value of labor productivity is less than the wages of labor in the local area, shallot farming is not feasible.

\subsubsection{Capital productivity}

Description:

$$
\text { Capital productivity }=\frac{N R-\text { own land rent-value FL }(H K O)}{\text { Total cost }} \times 100 \%
$$

$\begin{array}{ll}\text { NR } & \text { : Net Revenue } \\ \text { FL } & \text { : Family Labor } \\ \text { MD } & \text { : Man Day }\end{array}$

If capital productivity is from the savings interest rate, then the farm is feasible to run. If capital productivity is less than the interest rate of savings, then the farm is not feasible to run.

\section{Result and Discussion}

\subsection{Shallot Farming costs}

Farming costs are all expenses or sacrifices used in farming activities, including labor costs in the family and interest on own capital. In the production process, two kinds of costs must be incurred, namely explicit and implicit costs [6].

The calculations and data in Table 2 show that the explicit cost of farming environmentally friendly shallots is much lower $(30.49 \%)$ than the cost of conventional shallots. The total explicit cost of conventional shallots is $89,266,555$ IDR, and the total explicit cost of environmental shallots is $62,045,352$ IDR. The second explicit total cost of shallot farming is the highest for purchasing seeds, and the number of seeds is more in 
conventional shallots cultivation with the same variety, namely the Bima Brebes variety. The high cost of conventional shallot seeds is due to the closer spacing of $18 \times 20 \mathrm{~cm}$, while the environmentally friendly plant spacing is $20 \times 20 \mathrm{~cm}$. In addition to the cost of seeds, farm fertilizer costs are close to four times the cost of environmentally friendly fertilizer systems and the use of various fertilizers. Environmentally friendly shallot farming costs little because the type of fertilizer used is also small. In addition, there was no cost to buy pesticides. Farmers get free pesticides from the Agricultural Plant Protection Agency (BPTP) DIY, and some farmers make their own.

Table 2. Explicit cost of shallot farming for one season per hectare

\begin{tabular}{|l|r|r|r|r|}
\hline \multirow{2}{*}{ Description } & \multicolumn{2}{|c|}{ Environmentally Friendly } & \multicolumn{2}{c|}{ Conventional } \\
\cline { 2 - 5 } & Cost (IDR) & Percentage (\%) & Cost (IDR) & Percentage (\%) \\
\hline Seed & $43,575,000$ & 70.23 & $54,950,000$ & 61.56 \\
\hline Fertilizer & $4,416,633$ & 7.12 & $17,538,586$ & 19.65 \\
\hline Pesticide & 0 & 0.00 & 502,925 & 0.56 \\
\hline Out of work Labor & $1,896,388$ & 3.06 & $1,094,290$ & 1.23 \\
\hline Depreciation & $2,828,619$ & 4.56 & $4,970,509$ & 5.57 \\
\hline Equipment rental & $1,796,407$ & 2.90 & 887,978 & 0.99 \\
\hline Fuel & $3,702,536$ & 5.97 & $4,222,404$ & 4.73 \\
\hline Irrigation & $3,829,769$ & 6.17 & $5,004,235$ & 5.61 \\
\hline Group due & 0 & 0.00 & 95,628 & 0.11 \\
\hline Total & $62,045,352$ & 100.00 & $89,266,555$ & 100.00 \\
\hline
\end{tabular}

Based on the data from Table 3, the highest implicit costs are labor costs in the family (FL), both environmentally friendly shallots farming (57.34\%) and conventional (72.89\%). Farmers in Selopamioro Village still use family workers (husband and wife and assisted by parents) to manage their farms. It will reduce the explicit cost of labor wages. Farmers only use labor during land processing and planting because it requires more workforce.

Table 3. Implicit Cost of Shallot Farming per Hectare

\begin{tabular}{|l|c|c|r|r|}
\hline \multirow{2}{*}{ Description } & \multicolumn{2}{|c|}{ Environmentally Friendly } & \multicolumn{2}{c|}{ Conventional } \\
\cline { 2 - 5 } & $\begin{array}{c}\text { Cost } \\
\text { (IDR) }\end{array}$ & Percentage (\%) & $\begin{array}{c}\text { Cost } \\
\text { (IDR) }\end{array}$ & Percentage (\%) \\
\hline Own Capital Interest & $1,240,907$ & 9.50 & $1,785,331$ & 9.46 \\
Own Land Rent Value & $3,333,333$ & 25.51 & $3,333,333$ & 17.66 \\
Labor Family & $7,492,535$ & 57.34 & $13,759,444$ & 72.89 \\
Bio Pesticide & $1,000,893$ & 7.66 & 0 & 0.00 \\
Total & $13,067,668$ & 100.00 & $18,878,108$ & 100.00 \\
\hline
\end{tabular}

Based on Table 4, it is known that the total cost of shallots farming in environmentally friendly is 30.54 percent lower than the cost of farming conventional shallots. The percentage of explicit and implicit farming costs to the total costs in both systems is the same: explicit costs of 82.57 percent and implicit costs of 17.53 percent. The total cost of farming conventional shallots is quite large for the purchase of fertilizers. In contrast, environmentally friendly shallots do not spend much on fertilizers. There are no pesticide costs so that the total costs incurred are much lower.

Table 4. Total Cost of Shallot Farming per Hectare

\begin{tabular}{|l|c|c|c|c|}
\hline \multirow{2}{*}{ Description } & \multicolumn{2}{|c|}{ Environmentally Friendly } & \multicolumn{2}{c|}{ Conventional } \\
\cline { 2 - 5 } & Cost (IDR) & Percentage (\%) & Biaya (IDR) & Percentage (\%) \\
\hline Explicit cost & $62,045,352$ & 82.60 & $89,266,556$ & 82.54 \\
Implicit cost & $13,067,668$ & 17.40 & $18,878,108$ & 17.46 \\
\hline Total & $75,113,020$ & 100.00 & $108,144,664$ & 100.00 \\
\hline
\end{tabular}




\subsection{Revenue and profits of shallot farming}

The average price of shallots in both environmentally friendly and conventional farming systems is the same. It was caused of the harvest season is the same in the Selopamioro Village area, namely the planting season in May-June 2018. Farmers sell conventional and environmentally friendly shallots to traders by a slash. Data on acceptance, profit, and feasibility of shallot farming are presented in Table 5 .

The environmentally friendly shallots per hectare productions are $13.8 \%$ lower than conventional shallot production 7,876 tons/ha. Shallots farming revenue per hectare is higher than conventional shallots, which is IDR 193,714,966. It was influenced by the number of seeds released more than shallots with environmentally friendly so that the number of seeds more affects the amount of shallot production. Although the production and acceptance of farmers from environmentally friendly shallots is lower than conventional shallots, the profit obtained is $12.39 \%$ higher.

Table 5. Total Revenue and Profit Shallot Farming

\begin{tabular}{|l|c|c|}
\hline \multicolumn{1}{|c|}{ Description } & Environmentally friendly & Conventional \\
\hline Quantity (kg) & $7,876.5$ & 9,138 \\
\hline Price (IDR/kg) & 20,089 & 20,089 \\
\hline Total Revenue (IDR) & $171,291,020$ & $193,714,966$ \\
\hline Explicit Cost (IDR) & $62,045,352$ & $89,266,556$ \\
\hline Implicit cost (IDR) & $13,067,668$ & $18,878,108$ \\
\hline Total cost (IDR) & $75,113,020$ & $108,144,664$ \\
\hline Profit (IDR) & $96,178,000$ & $85,570,302$ \\
\hline
\end{tabular}

Shallots farming revenue per hectare is higher than conventional shallots, with total revenue of IDR 193,714,966. It was influenced by the number of seeds released more than the shallots with organic treatment so that the more number of seeds also affects the amount of shallot production. However, environmentally friendly shallot farmers gain 12.40 percent greater profits. This significant advantage is because the total cost of environmentally friendly shallots is smaller than conventional shallots. The results of this study support research [11], which states that organic farming provides higher net income to farmers than conventional farming.

\subsection{Feasibility of Shallot Farming}

Table 6. Feasibility of Shallot Farming in Selopamioro Village

\begin{tabular}{|l|c|c|}
\hline Description & Conventional & Environmentally Friendly \\
\hline Revenue (IDR) & $193,714,966$ & $171,291,020$ \\
\hline Total cost (IDR) & $108,144,664$ & $75,113,019$ \\
\hline Income (IDR) & $104,448,410$ & $109,245,669$ \\
\hline Value FL(IDR) & $13,759,444$ & $1,585,413$ \\
\hline Own Capital Interest (IDR) & $1,785,331$ & $1,240,907$ \\
\hline Own land rent (IDR) & $3,333,333$ & $3,333,333$ \\
\hline FL (HKO) & 250 & 121 \\
\hline Explicit cost (IDR) & $89,266,556$ & $62,045,352$ \\
\hline R/C & 1.79 & 2.28 \\
\hline Land productivity & 8,890 & 10,642 \\
\hline Labor productivity & 397,319 & 865,053 \\
\hline Capital productivity & 97,86 & 158,63 \\
\hline
\end{tabular}


The feasibility of shallots farming is a way to test whether farming is feasible or not to continue. The feasibility of farming can be calculated through several criteria, including R/C, Land Productivity, Capital Productivity, and Labor Productivity. The results of the feasibility analysis of environmentally friendly and conventional shallot farming can be seen in Table 5.

Both environmentally friendly and conventional shallot farming was feasible to cultivate by farmers. It was indicated with the value of $\mathrm{R} / \mathrm{C}$ ratio that more than 1 , Land productivity was greater than the land rent value in Selopamioro Village of 2,000 per $\mathrm{m}^{2}$ for one growing season. On the other hand, the capital productivity is greater than the BRI savings interest rate of $0.70 \%$ per year, and labor productivity is higher than farmers' wages in the Selopamioro Village area. The feasibility of conventional shallots in Selopamiro Village is more feasible than shallot farming in the Districts of Sanden, Srandakan, and Kretek, with an $\mathrm{R} / \mathrm{C}$ value of 1.40 [12]. The results of this study indicate that shallot farming is feasible even the $\mathrm{R} / \mathrm{C}$ ratio value was different [13] with shallots in Majalengka Regency, [14] shallots in Torongrejo Village, Batu City, [15] shallots in Sajen Village Pacet District, Mojokerto Regency. Even environmentally-friendly shallot farming feasibility is much higher than conventional shallot farming on all feasibility indicators. The feasibility of shallots farming, both environmentally friendly and conventional in Selopamioro Village, is higher than farming in Guntarano Village, Donggala Regency, Central Sulawesi. The $\mathrm{R} / \mathrm{C}$ ratio in Guntarano Village is $\mathrm{R} / \mathrm{C}$ of 1.67 for shallot farming that adopts an environmentally friendly agricultural system and $\mathrm{R} / \mathrm{C}$ of 1.45 for those who do not adopt the system [16]. Furthermore, the feasibility of red shallots farming in Tegal Regency with an R/C value of 2.99 for the recommended environmentally friendly shallots cultivation business and an $\mathrm{R} / \mathrm{C}$ of 2.40 carried out by farmers [9]. This study provides a great opportunity to be developed more widely in shallot production centers in Bantul Regency and shallot production centers in Indonesia.

\section{Conclusion}

Shallot farming in Selopamioro Village is feasible to cultivate, both environmentally friendly and conventional cultivation systems. The production and acceptance of environmentally friendly shallot farming are lower than conventional shallot farming. However, the costs, benefits, and feasibility of environmentally friendly shallot farming are higher. Developing an environmentally friendly shallot cultivation business must receive support from farmers as actors and the local government to provide better support and assistance.

Acknowledgements. On this occasion, the authors would like to thank LP3M University of Muhammadiyah Yogyakarta, which has provided opportunities and financial support so that this research can be carried out properly. And not to forget the farmers and the head of farmer groups in Nawungan 1 and Nawungan 2 who have provided the data and information the authors need so that the publication of the results of this research can be useful and add to the scientific treasures of environmentally friendly agricultural systems.

\section{Reference}

1. Badan Pusat Statistik dan Direktorat Jenderal Hortikultura, "Produksi Bawang Merah Menurut Provinsi, Tahun 2015-2019," Data Lima Tahun Terakhir Kementeri. Pertan. Republik Indones., vol. 2019, p. 1, (2019). 
2. Kemendag RI, "Profil Komoditas Bawang Merah," (2020).

3. A. Organis Pertanian, "Statistik Pertanian Organik 2016," Indonesia, (2017)

4. B. S. Nasional, "Sistem Pertanian Organik." (2016).

5. A. Wihardjaka, "Penerapan Model Pertanian Ramah Lingkungan sebagai Jaminan Perbaikan Kuantitas dan Kualitas Hasil Tanaman Pangan," Pangan, vol. 27, no. 2, pp. $155-164$, (2018).

6. A. Wihardjaka, "Penerapan Model Pertanian Ramah Lingkungan sebagai Jaminan Perbaikan Kuantitas dan Kualitas Hasil Tanaman Pangan," Pangan, vol. 27, no. 2, pp. 155-164, (2018).

7. D. Badan Pusat Statistik, "Produksi Sayur-sayuran menurut Jenisnya dan Kabupaten/Kota di D.I. Yogyakarta (kwintal)," DIY, Badan Pusat Statistik, (2017).

8. E. Iskandarsyah and A. Nursalikah, "Panen Perdana Bawang Merah Organik Bantul," Republika.co.id, (2018).

9. T. C. Mardiyanto, T. R. Prastuti, and R. Pangestuti, "Analisis Kelayakan Usaha Budidaya Bawang Merah Ramah Lingkungan di Kabupaaten Tegal," AGRONOMIKA, vol. 12, no. 1, pp. 34-39, (2017).

10. K. Suratiyah, Ilmu Usahatani, Edisi Revi. Yogyakarta: Penebar Swadaya, (2020).

11. K. K. A. A. M. Hamdani, "Kajian Usahatani Bawang Merah di Kecamatan Pabuaran,Kabupaten Cirebon," (2020).

12. M. Fauzan, "Pendapatan, Risiko dan Efisiensi Ekonomi Usahatani Bawang Merah di Kabupaten Bantul," Agrar. J. Agribus. Rural Dev. Res., vol. 2, no. 2, pp. 107-117, (2016.)

13. L. Rahmadona, A. Fariyanti, and B. Burhanuddin, "Analisis Pendapatan Usahatani Bawang Merah Di Kabupaten Majalengka,” J. AGRISE, vol. XV, no. 2, pp. 72-84, (2015).

14. L. D. Lulita, "Analisis Produksi dan Pendapatan Usahatani Hortikultura Bawang Merah di Kota Batu ( Studi Kasus Gapoktan Torong Makmur Desa Torongrejo , Kecamatan Junrejo Kota Batu )," Sos. Hum., (2018).

15. Y. H. Putra, Dwi Susilowati, and Farida Syakir, "Analisis Risiko Usahatani Bawang Merah di Desa Sajen Kecamatan Pacet Kabupaten Mojokerto," J. Sos. Ekon. Pertan. dan Agribisnis, vol. 8, no. 2, pp. 49-58, (2020).

16. M. Mahfudz et al., "Adoption and advantages of eco-friendly technology application at the shallot farming system in Indonesia," Agron. Res., vol. 17, no. 4, pp. 1679-1687, (2019). 